\title{
The recent Canadian record in applied biological control of forest insect pests ${ }^{1}$
}

\author{
by
}

\author{
Michael A. Hulme ${ }^{1}$
}

\begin{abstract}
The applied biological control of 21 forest insect pests was recently evaluated in Canada. One-third of these pests have been almost permanently controlled in their present environment. One-third of the pests can be controlled for one to several pest generations. The remaining third were either not controlled or the evaluation of the applied biological control has not been completed. Benefit:cost data are scant and those available are rudimentary. Ratios of at least $20: 1$ were calculated for two successes with long-term control. Higher ratios were obtained when the control economics were examined from the perspective of the forest manager. Only the production of Bacillus thuringiensis is sufficiently profitable for private industry to undertake supply. Applied biological control has a good record of environmental compatibility. Prospects for the control method are briefly outlined.
\end{abstract}

\section{Résumé}

Des spécialistes ont récemment évalué les moyens de lutte biologique mis en oeuvre contre 21 ravageurs forestiers au Canada. Le tiers de ces ravageurs a été réprimé de façon quasi-permanente dans leur site d'extension actuelle. Le niveau des populations d'un autre tiers de ces ravageurs peut être contrôlé pendant une à plusieurs générations. Les sept autres espèces n'étaient pas réprimées ou l'évaluation des mesures de lutte n'a pas été complétée. Nous disposons de très peu de données sur les ratios avantages-coûts, données qui sont d'ailleurs fort rudimentaires. Nous avons calculé des ratios d'au moins $20 / 1$ pour deux techniques fructueuse de lutte à long terme. Ces ratios sont encore plus élevés lorsque l'aspect économique de la lutte est examiné du point de vue de l'aménagiste. Seule la production commerciale de Bacillus thuringiensis est suffisamment rentable pour l'industrie privée. Les méthodes de lutte biologique semblent bien s'harmoniser avec l'environnement. Les perspectives d'avenir des méthodes de lutte biologique sont exposées brièvement.

\section{Introduction}

Every year Canada's forests sustain immense damage from insects (Kondo and Taylor 1986) and foresters have used a variety of methods to attempt to reduce or prevent this injury. One of the oldest methods of insect control (Needham et al. 1986) which can be used alone or in combination with other methods is to apply natural enemies of the pest to regulate its abundance - so-called biological control. Regulation of insect numbers by natural enemies or by other natural factors such as weather is already widespread in nature since relatively few of the aproximately one million insect species so far described multiply to become pests (Askew 1971). Indeed, the described species may be only $5 \%$ of all insect species (Erwin 1982). Many examples of naturally-occurring biological control are already documented (e.g. Huffaker 1977).

The record of applied biological control stretches back almost two millennia. The Talmud records the earliest known example of man applying biological control - in second century Israel (Harpaz 1973). The Chinese have recorded

Canadian Forestry Service, Pacific Forestry Centre, 506 West Burnside Road, Victoria, B.C. V8Z $1 \mathrm{M5}$ continuous use of such methods since the fourth century (Hsi Han 304), but in western literature the earliest account was written in the eighteenth century (Forskål 1775). Canadian application of biological control essentially belongs to this century and the present article summarizes our more recent experience with forest insect pests.

Natural enemies of insects can be grouped in many ways though not all organisms fit neatly into the chosen system. Here, I group natural enemies into predators - organisms that devour several prey - and parasites - organisms that feed from their host without initially killing it. Most predators considered here are insects. One vertebrate, the masked shrew, was used but its impact on the target pest was not measured; other small mammals and birds are well known to eat insects but none has been applied for insect pest control. The parasites may be either parasitic insects (which comprise over $10 \%$ of all described animal species - Askey 1971), or entomopathogens (bacteria, viruses, protozoa, fungi and nematodes) that infect the insect and cause a variety of usually fatal insect diseases.

Two main approaches have been used to apply natural enemies, the choice largely depending on whether the target 
pest is exotic or native. If an exotic insect is accidentally introduced into the forest and becomes a pest, it is probably not accompanied by all its natural enemies; hence, small numbers of natural enemies are normally collected from the pest's foreign habitat and introduced in the hope that they will multiply in the new environment and control the pest. Successful control generally results in long-term reduction of pest damage. If a native insect becomes a pest, natural enemies found locally, are reared and released in numbers that inundate the pest's environment. These increased numbers are not maintained indefinitely and future generations of the pest will eventually need treating if control is to be maintained.

In examining any method of controlling insects most questions relate to how well the pest is controlled, what the control costs, and how it affects the environment. Hence, this brief review evaluates applied biological control of forest insects pests in Canada under headings of control efficacy, return on investment, and compatibility with the environment.

\section{Control Efficacy}

Canadian attempts with applied biological control were last examined during the decade of the 1970's and involved 21 target insects. Two-thirds of these targets were considered to be successfully controlled, i.e., damage was regulated at levels that the forest manager or general public (with urban trees) could tolerate (Table 1). Detailed biological accounts of these evaluations are published elsewhere (Kelleher and Hulme 1984).

Half of the successes have resulted in virtually permanent control of most damage without need for further intervention these result from introductions of exotic natural enemies to control exotic insect pests. A few years are needed for the natural enemies to spread through the pest population and control pest damage. If the target pest is patchily distributed. introductions may be needed in each isolated patch. The controlled pests are European spruce sawfly ${ }^{2}$ on spruces, larch casebearer and larch sawfly on larches, mountain-ash sawfly on mountain ashes, satin moth on poplars and willows, winter moth on many deciduous trees especially oaks, and European pine shoot moth in plantations of hard pines. The controlled insect is not exterminated but is held in check. Thus local pest damage still occurs when the ecological balance between pest insect and its introduced natural enemies is disturbed. For example, the European spruce sawfly, which earlier this century was devastating eastern Canadian forests on a scale rivalling the damage now wreaked by spruce budworm, was controlled by introductions of two parasitic insects and a virus. However, during the 1960's the equilibrium between host and parasites was temporarily disturbed by applications of DDT insecticide intended to control spruce budworm; an irruption of the forgotten sawfly occurred for a number of years after spraying ceased but eventually pest damage subsided as the pre-spray equilibrium between host and parasites became re-established (Nielson et al. 1971).

The remaining half of the successes all involved inundating the environment of native insect pests with entomopathogens. Controllable pests include Douglas-fir tussock moth on Douglas-fir, European pine sawfly on pines, forest tent caterpillar on many deciduous trees (especially trembling aspen), redheaded pine sawfly in plantations of hard

2Insect nomenclature follows the common names of insects approved by the Entomological Society of America (Werner 1982). pines, spruce budworm on spruces and balsam fir, Swaine jack pine sawfly on jack pine, and whitemarked tussock moth on balsam fir and many deciduous trees. The period of control following inundation varied depending upon how long the entomopathogen maintained its high numbers in the pest population. The bacterium Bacillus thuringiensis (Bt) was by far the most extensively applied entomopathogen. The selected isolate of the bacterium produces a toxin that stops a range of moth and butterfly larvae feeding within hours of ingesting the bacterium although the insect may not die for several days. Here, control was confined to the pest generation treated with $B t$ because normally the bacterium is not found naturally in these pests and did not spread well to succeeding generations. Thus the objective when using $B t$ has been immediate protection of foliage rather than extended suppression of insect epidemics. The main target for $B t$ in the 1970's, spruce budworm, was still the main target by the mid1980 's; the other treated infestations in recent years were mainly jack pine budworm and gypsy moth (evaluation of success is in progress). Usage of $B t$ has expanded rapidly in recent years reflecting good acceptability of the control treatment: in $1983,3 \%$ of the 2.8 million ha of sprayed forest were treated with $B t$; by $1984,22 \%$ of 1.8 million ha sprayed were treated with $B t$; and by $1985, B t$ treatments accounted for $52 \%$ of the 1.7 million ha of sprayed forest (Morris et al. 1986). In $198663 \%$ of 1.6 million ha were treated with Bt (Anon. $1987 a)$. The remaining successes utilizing inundation were all with baculoviruses (a group of insect viruses) obtained from the target pest or a close relative (Cunningham 1982). Pest damage still occurred for several days after application because the viruses needed this time to multiply within the pest and stop insect feeding; eventually they kill the insect. Most applied viruses were transferred to successive pest generations by various natural events resulting in several years of pest control. For example, control of Douglas-fir tussock moth is expected to last about 9 years (Shepherd and Otvos 1986). Eventually the pest population becomes relatively free of the applied entomopathogen and a reapplication is needed to maintain pest control.

Some attempts with biological control have not been evaluated and are listed as "success unknown" in Table 1. There are good theoretical reasons to expect some successes here when data are eventually collected. Even some unsuccessful attempts may well be reversed with further work: for example, western spruce budworm was not controlled by $B t$ in the 1970's when knowledge of its production and application to forests was in its infancy.

\section{Return on Investment}

Three main perspectives dominate Canadian thought: the national cost of developing and applying biological controls relative to the national benefits; the cost to the forest manager of using biological controls relative to the benefit of increased wood production; and the profitability of privately producing natural enemies for sale to forest managers. Unfortunately, data are scarce for all three perspectives.

From the national perspective, costs of research and development can be obtained from government records since most work was government funded. Benefits, however, accrue in many ways and are more complex to quantify: they include increased wood supply (whether values are measured on the stump, at the roadside, at the mill, or by end product), increased forestry employment, improved aesthetics, better environmental protection (e.g. for wildlife or shelterbelts), national spin-off in scientific research, and so on. No such comprehensive 
Table 1. Examples of the efficacy of applied biological control against 21 forest insect pests

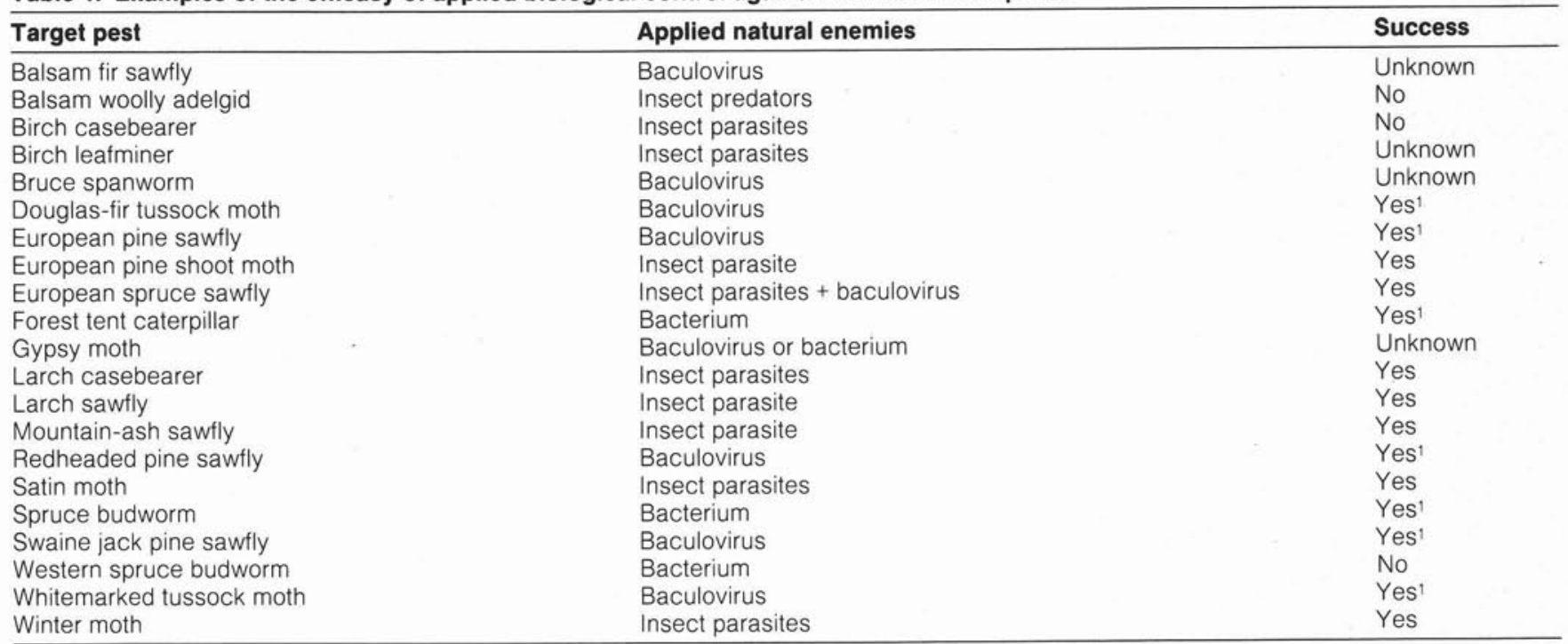

Re-application of the natural enemies to some future pest generations is needed to maintain control

analyses have been carried out. The incomplete perspective so far obtained is confined to the one-third of control attempts listed in Table 1 that resulted in virtually permanent pest control. Here, development and application costs have ended while benefits continue to accrue at a rate determined by the assumptions made if the pest had remained uncontrolled. Clearly, the longer the control lasts, the more profitable it becomes. Looking just at wood supply, control of European spruce sawfly cost about $\$ 300000$ in 1940 immediately saving 8.5 million cords of wood nominally valued at $\$ 6$ million and potentially saving at least a further 500 million cords of wood that would have been destroyed if the insect had remained uncontrolled into the 1960's (Reeks and Cameron 1971). Similarly, control of winter moth in Nova Scotia by parasitic insects introduced in the late 1950's cost approximately $\$ 160000$ when the roadside value of the 1.5 million cords of oak not yet killed was about $\$ 12$ million and approximately $\$ 2$ million worth of oak had already been lost (Embree 1971). Although rudimentary, these analyses already show the large return on investment possible with the successful application of long-term biological control. The remaining successful control attempts in Table 1 all resulted in short-term control, but here no benefit:cost analyses have been undertaken. Clearly, given the paucity of data, no overall national view can be drawn that includes all successes and failures. Indeed, only one country has attempted such a summary: in Australia two-thirds of 12 pest management attempts using biological control were successful and the overall benefitcost ratio obtained by combining all 12 attempts was 10:1 (Marsden et al. 1980).

When examining return on investment from the perspective of the forest manager, applied biological control should again be divided into long-term and short-term control. Long-term control, involving releases of exotic natural enemies, normally has cost the forest manager little or nothing because most direct expense was borne by the federal government. Where such control was successful, benefits would accrue as outlined above in terms of wood produced and provide the forest manager with an immense return on investment. Short-term control using entomopathogens has cost the forest manager more than treatments with chemical insecticides. In the 1970's, Bt treatments cost about 10 times more than treatments with chemical insecticides, a difference that has narrowed to a current value of about two-fold as $B t$ treatments were refined through improved production, formulation, and application (Cunningham 1985). This change resulted in $B t$ treatment costs remaining fairly stable in recent years despite the use of higher dosages and despite increased costs of all aerial applications. For example, treatment costs in Quebec for small-scale operations were \$29 per ha in 1981 (Morris 1982), \$25 per ha in 1985, and $\$ 31$ per ha in 1986 (Juneau and Robert 1986). Use of successful viruses had not expanded to commercial production and application: Canadian production has been in research laboratories and is thus expensive to forest managers. Producing the virus to control Douglas-fir tussock moth was recently estimated to cost $\$ 50$ per ha (Morris et al. 1986). Most of the viruses that control sawflies could be produced on a small scale by infecting selected field colonies of the pest; production costs using this system were estimated at $\$ 2.50$ per ha (Cunningham and McPhee 1986). Production of a virus that infects gypsy moth is not carried out in Canada but is being financed by the USDA Forest Service and the control potential of the virus is currently being evaluated in eastern Canada. (In the United States only two viral insecticides are marketed by private companies, both for control of European pine sawfly.) Benefits of applying a control product like a virus that can control damage for several pest generations have not been quantified.

Finally, examining return on investment from the perspective of the producer of natural enemies shows that in most cases private production would not be sufficiently profitable. This conclusion applies to most western economies (e.g., Anon. 1977). Natural enemies that are the most successful in long-term control of pests - the exotic natural enemies are commercially the least attractive because each is effective against only one pest and one application lasts indefinitely. Proprietary rights are also difficult to establish and protect. Most natural enemies used for short-term control are also commercially unattractive because, again, most can be applied to only one or two pests and re-application may not be needed for several years. The notable exception is $B t$ which has neither of these two constraints: 16 commercial formulations are registered for forestry use in Canada (Anon. 1987b), although none of the $B t$ is produced here (Morris et al. 1986). Indeed, no entomopathogens are produced commercially in this country. 


\section{Environmental Compatibility}

Applied biological control of forest pests has a good record of public acceptability. The exotic natural enemies so far introduced are considered environmentally benign since they primarily operate on the ecology of the pest insect and sometimes its close relatives. Government regulatory agencies operate a quarantine system to ensure that future introductions are safe. Entomopathogens, regardless of their origin, must also have government registration of environmental safety: most of these natural enemies are already found in the pest's environment but not in such quantities nor with the carriers and sprays in which they are applied. Bacillus thuringiensis received regulatory approval many years ago. Approval to use viruses for commercial pest control was not sought until the 1980's. So far, two approvals have been requested and restricted approval has been granted to use the viruses for Douglas-fir tussock moth and for redheaded pine sawfly under supervision of federal or provincial forestry service personnel (Anon. 1987c). The virus for Douglas-fir tussock moth is also being tested against whitemarked tussock moth. Viruses for gypsy moth and European pine sawfly are approved by foreign regulatory agencies; approval for the use of the latter in Canada is currently being sought.

\section{Prospects for Further Success}

Apart from details needed to complete research findings on the list of controllable pests, opportunities exist to upgrade short-term to long-term control and to find controls for some of the refractory pests. There are also opportunities to explore applied biological control with pests not yet examined, although such control methods are not expected to be suitable for all pests.

Control attempts with the methods outlined above are far from exhausted. Exotic natural enemies should continue to be found that can control insect pests; effort has been devoted to exotic pests but native ones could also be examined following the example of other countries where exotic natural enemies have been found that complemented or improved on control by native natural enemies (e.g. Bustillo and Drooz 1977; Carl 1982). Successful controls should be highly profitable for the forest manager and be environmentally benign. New entomopathogens suitable for inundation should continue to be found. Isolates of $B t$, for example, have been found that are toxic to beetles rather than moths and butterflies (the targets of currently registered Bt products for forestry). Inundation with entomopathogens will continue to be relatively expensive until production is modified and application refined (e.g. Sherman 1985); treatment with Bt has progressed well here, a trend that should continue. Judging from experience with application methods used in the past, the impact of these inundations on the environment should remain small. These environmental considerations may often eclipse other selection criteria for pest control (Pimentel 1985). Production of most traditional natural enemies seems likely to remain government supported since industry alone probably would not be able to make sufficient profit.

The genetic engineering of new natural enemies offers enticing research opportunities and yet presents potential risks to the environment that need thorough evaluation before any releases are attempted. In North America, the evaluation is in progress and no releases in forests are permitted; recently, the Canadian regulatory authority outlined its requirements for permitting testing (Hollebone 1987). In Britain, larvae of the beet armyworm infected with an engineered virus have been released outdoors on plants (covered with wire netting to exclude large predators) to see how long the virus survives. The British similarly planned the release of an engineered virus to infect pine beauty moth (the noctuid Panolis flammea) on lodgepole pine trees covered with wire netting (Anon. 1986). One possible outcome of the research will be to insert into the virus the genetic material from $B t$ responsible for producing a toxin that stops insect feeding within a few hours - a natural insect virus takes several days to halt feeding. The feasibility is also being considered of building a "self-destruct" feature into the virus that would be activated once it has done its job. In the United States the genetic material from Bt responsible for toxin production has also been inserted into a bacterium found on the roots of corn plants; insects feeding on corn roots were thus killed in greenhouse trials and also in field trails using dead bacteria (Hollebone 1986). Canadian researchers are also using a bacterium that causes plant tumors to transfer the same genetic material from $B t$ directly into plants so that the plant itself can produce the toxin (Crosby 1986). Tobacco plants were recently produced in Belgium by this method and were protected in the laboratory from feeding damage by larvae of the tobacco hornworm (Vaeck et al. 1987).

In summary, the proven track record of old techniques and the myriad opportunities with new techniques offer many possibilities for further successful application of biological control to forest insect pests.

\section{References}

Anon. 1977. New innovative pesticides: an evaluation of incentives and disincentives for commercial development by industry. Stanford Res. Inst. Menlo Park, California.

Anon. 1986. Engineered virus in U.K. Biocontrol News and Inf. 7:63.

Anon. 1987a. The 1986-1987 forestry spraying programs. Forest Resource Environment News 3(2): 7 .

Anon. 1987b. Bacillus thuringiensis. Insecticide Technical Reference. Can Pulp Paper Assoc. and For. Pest Manage Inst. 4 pp.

Anon. 1987c. Nuclear polyhedrosis viruses. Insecticide Technical Reference. Can Pulp Paper Assoc. and For. Pest Manage Inst. 4 $\mathrm{pp}$.

Askew, R.R. 1971. Parasitic Insects. Heinemann, London

Bustillo, A.E. and A.T. Drooz. 1977. Cooperative establishment of a Virginia (USA) strain of Telenomus alsophilae on Oxydia trychiata in Colombia. J. Econ. Entomol. 70: 767-770.

Carl, K. 1982. Biological control of native pests by introduced natural enemies. Biocontrol News and Inf. 3: 191-200.

Crosby, W. 1986. Plants engineered to make their own insecticide. Biotech. Bull. 1: 5-6.

Cunningham, J.C. 1982. Field trails with baculoviruses: control of forest insect pests. In E. Kurstaki (Ed.) Microbial and Viral Pesticides. Marcel Dekker, New York pp. 335-386.

Cunningham, J.C. 1985. Biorationals for control of spruce budworm. In J.C. Sanders, R.W. Stark, E.J. Mullins and J. Murphy (Eds.) Recent Advances in Spruce Budworms Research. Min. of Supply and Serv., Ottawa. pp. 320-349

Cunningham, J.C. and J.R. McPhee. 1986. Production of sawfly viruses in plantations. Tech. Note 4, For. Pest Manage. Inst., Sault Ste. Marie, 4 pp.

Embree, D.G. 1971. The biological control of the winter moth in eastern Canada by introduced parasites. In C.B. Huffaker (Ed.) Biological Control. Plenum, New York. pp. 217-226.

Erwin, T.E. 1982. Tropical forests: their richness in coleoptera and other arthropod species. The Colleopterists Bull. 36: 74-75.

Forskål, P. 1775. Descriptiones animalium avium, amphibium, piscum, insectorum, vermium; quae in itinere orientali, observait $P$. Forskal. Hauniae, Moeller.

Harpaz, I. 1973. Early entomology in the Middle East. In R.F. Smith, T.E. Mittler, and C.N. Smith (Eds.) History of Entomology. Annual Reviews Inc. Palo Alto, California. pp. 21-36

Hsi Han. 304. Na Fang Tshao Mu Chuang. Translated by Li Hui-Lin under the title: Records of the Plants and Trees of the Southern Regions. The Chinese University Press, Hong Kong, 1979, 168 $\mathrm{pp}$ 
Hollebone, JE. 1986. New generation insecticides. Plenary paper to the Ent. Soc. of Canada and the Ent. Soc. of Manitoba, Oct. 6.

Hollenbone, J.E. 1987. Memorandum to registrants re: regulation of pesticides produced by biotechnology. No. R-1-231 Food Production and Inspection Branch, Agriculture Canada. 5 pp.

Huffaker, C.B. (Ed.) 1971. Biological Control. Section III. The unheralded naturally-occurring biological control. Plenum, New York pp. 253-327.

Juneau, A. and J. Robert. 1986. Aerial spraying with Bacillus thuringiensis on private woodlots in eastern Quebec. Can. For. Serv. Special Rep., Ste. Foy, Quebec.

Kelleher, J.S. and M.A. Hulme. (Eds.) 1984. Biological Control Programmes against Insects and Weeds in Canada. 19691980. Commonwealth Inst. of Biological Control, Slough, U.K.

Kondo, E.S. and R.G. Taylor. 1986. Forest Insect and Disease Conditions in Canada 1985. Min. of Supply and Serv., Ottawa.

Marsden, J.S., G.E. Martin, D.J. Parham, T.J. Ridsill Smith, and B.G. Johnston 1980. Returns on Australian agricultural research: joint IAC-CSIRO benefit cost study of the CSIRO Division of Entomology. Commonwealth Scientific and Industrial Research Organization, Canberra.

Morris O.N. 1982. Report of the 1981 cooperative Bacillus thuringiensis spray trials. Can. For. Serv. Rep. FPM-X-58, Sault Ste. Marie, Ontario.

Morris, O.N., J.C. Cunningham, J.R. Finney-Crawley, R.P. Jaques and G. Kinoshita. 1986. Microbial insecticides in Canada: their registration and use in agriculture, forestry and public and animal health. Ent. Soc. Canada Special Rep., Ottawa.
Needham, J., Lu Gwei-Djen and Huang Hsing-Tsung. 1986. Science and Civilisation in China 6: Biology and Biological Technology Part 1 Botany. Cambridge University Press.

Nielsen, M.M., R. Martineau, and A.H. Rose. 1971. Diprion hercyniae (Hartig), European spruce sawfly. In Biological Control Programmes against Insects and Weeds in Canada 1959-1968. Tech. Comm. 4. Commonwealth Inst. of Biological Control, Slough, U.K. pp. 136-143.

Pimentel, D. 1985. Pests and their control. In N.B. Mandava (Ed.) CRC Handbook of Natural Pesticides: Methods. Volume 1. Theory Practice and Detection. CRC Press Inc. Boca Raton, Florida. pp. 3-19

Reeks, W.A. and J.M. Cameron. 1971. Current approaches to biological control of forest insects. In. Biological Control Programmes against Insects and Weeds in Canada 1959-1968. Tech. Comm. 4. Commonwealth Inst. of Biological Control, Slough, U.K. pp. 105-113.

Shepherd, R.F. and I.S. Otvos. 1986. Pest management of Douglasfir: procedures for insect monitoring, problem evaluation and control actions. Can. For. Serv. Rep. BC-X-270, Victoria, B.C.

Sherman, K.E. 1985. Considerations in the large-scale and commercial production of viral insecticides. In Maramorosch and K.E. Sherman (Eds.) Viral Insecticides for Biological Control. Academic Press, Orlando, Florida, pp. 757-774.

Vaeck, M., A. Reynaerts, H. Hofte, S. Jansens, M. De Beuckeleer, C. Dean, M. Zabeau, M. Van Montagu and J. Leemans. 1987. Transgenic plants protected from insect attack. Nature 328: 33-37

Werner, F.G. (Chairman). 1982. Common Names of Insects 1982. Ent. Soc. of America, Maryland.

\section{Forestry Position Macdonald College of McGill University}

The Department of Renewable Resources, Faculty of Agriculture, McGill University, invites applications for a full-time tenure track position at the rank of assistant professor in Woodland Resources, commencing August 1, 1988 or thereafter. A Ph.D. is required in one of the following areas: forest ecology, urban forestry, forest atmosphere interactions, private forest management, forest protection or forest technology transfer.

Effective communication skills in both English and French, experience in applied forest management and eligibility for membership in l'Ordre des Ingenieurs forestiers du Québec are desirable.

The successful applicant will be expected to teach undergraduates and graduate students and to develop an active research programme associated with the 240 ha Morgan Arboretum, which provides excellent research opportunites. Salary will be based on a floor value of $\$ 33,997$ and will be commensurate with qualifications and experience. In accordance with Canadian immigration requirements, this advertisement is directed to Canadian citizens and permanent residents in the first instance.

Send applications with a detailed curriculum vitae and the names of three referees by March 15, 1988 to:

Dr. R.D. Titman, Chairman, Department of Renewable Resources, Macdonald College of McGill University, 21, 111 Lakeshore Road, SteAnne-de-Bellevue, Quebec, Canada. H9X $1 \mathrm{CO}$. 